\title{
Perspective
}

\section{Israel's Interests and Options in Syria}

\author{
Larry Hanauer
}

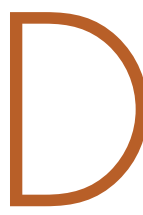
espite efforts by the United States, Europe, Turkey, and Iraq to keep the Syrian civil war contained within that country's borders, the instability that the conflict has created has spilled over into the region and beyond. Syrian refugees have flooded into Europe, creating a political crisis that threatens to reverse the foundations of European unity-most notably, the Schengen Agreement's elimination of internal borders

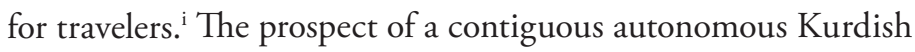
zone along the Syria-Turkey border has caused Turkey to reevaluate its approach to its own Kurdish population, which had, until mid-2015, appeared to be on the verge of normalizing Kurdish participation in the Turkish polity. Finally, the so-called Islamic

\footnotetext{
Schengen Agreement is the commonly used short name for the Agreement Between the States of the Benelux Economic Union, the Federal Republic of Germany and the French Republic on the Gradual Abolition of Checks at Their Common Borders (Benelux Economic Union, Federal Republic of Germany, and French Republic, 1985).
}

State of Iraq and Syria (ISIS) has captured territory in both Syria and Iraq, and ISIS has used its strongholds there (and the resources it derives from governing these states) to support affiliates throughout the Middle East and to inspire dramatic terrorist attacks in Europe and the United States.

Although it is located adjacent to the conflict, Israel has very different interests in Syria from those of other Western countries. Whereas the United States and Europe are concerned principally about the destabilizing regional influence of Sunni extremists, such as ISIS and al Qaeda, and the potential that these groups will instigate attacks on U.S. and European territory, Israel is concerned primarily about the influence that Iran exerts so close to Israel's borders. ${ }^{1}$

Although violent Sunni extremists in Syria could turn their attention toward Israel at some point, to date, they have been more interested in expanding their influence in the Arab world by fighting each other, undermining Arab regimes that they see as 


\section{The multi-factional civil war in Syria threatens the stability of U.S. allies in Turkey, Jordan, and Iraq . . . but it does not, in and of itself, pose an immediate threat to Israeli security.}

illegitimate, killing and enslaving non-Sunnis (such as Shi'a and Yazidis), and resisting the Shi' a regime in Iran and its allies (including the Syrian government of Bashar al-Assad). The multi-factional civil war in Syria threatens the stability of U.S. allies in Turkey, Jordan, and Iraq - and it has driven hundreds of thousands of refugees to flee toward Europe-but it does not, in and of itself, pose an immediate threat to Israeli security (with the exception of the occasional stray artillery shell that inadvertently lands in Israeli territory).

Continuing stalemate, in fact, could serve Israel's short-term interests more than the emergence of a clear victor that might then seek out a conflict with Israel to build legitimacy. The unpalatability of any likely outcome-a decisive victory by an Iranian-backed Assad regime or the disintegration of Syria into disparate fiefdoms run by Sunni extremists, Iranian-backed militias, Alawites, and other actors-has deterred Israel from taking sides in Syria's civil war. $^{2}$ Summarizing Israeli prime minister Benjamin Netanyahu’s discussions with Russian president Vladimir Putin, Israeli minister of defense Moshe Ya'alon stated, "[W]e are not involved in who will control Syria. Assad or not Assad, we are not entering that discussion at all."3

One of Israel's principal concerns in Syria has been the extent of Iranian influence, both through the deployment of Iranian troops and through Tehran's extensive support to Hezbollah. Iran's deployment of significant numbers of troops ${ }^{\mathrm{ii}}$ and Hezbollah's mobilization of thousands of fighters ${ }^{\mathrm{iii}}$ to support the Assad regime has exacerbated Israel's concerns. Iran's position in Syria has been strengthened by the Russian military intervention on behalf of the Assad regime, which, by targeting Sunni militias, has given Iran and its partners greater room to maneuver and potentially constrains Israel's ability to act militarily. Israel has launched attacks into Syrian territory - including by striking convoys of Iranian troops and Hezbollah fighters-but it has done so only in limited ways that pre-empt attacks on Israel while minimizing the chances for a direct conflict between Israel and Iran.

With little ability to affect the outcome of the Syrian civil war, ${ }^{4}$ and with limited interest in intervening in the conflict other than to pre-empt or respond to attacks on its territory, ${ }^{5}$ Israel seems to have been a passive actor in recent events shaping the Levant. But Israel does have critical security interests at stake, and it has pledged to protect them vigorously. Unless and until the Syrian conflict dramatically changes course, Israel's strategy will likely be to monitor events carefully, work with Moscow to minimize the chances of inadvertent conflict with Russia, and take as few direct actions as are necessary to protect Israel's territory and citizens.

\footnotetext{
ii Estimates of Iran's troop presence in Syria in early October 2015 ranged from 2,000 (as Gen Joseph Dunford, Chairman of the Joint Chiefs of Staff, suggested) ("Iran Has over 1,000 Troops in Iraq," 2015) to 7,000 (as reported in the Wall Street Journal) (Dagher and Fitch, 2015).

iii In July 2015, Hezbollah was believed to have 6,000 to 8,000 fighters deployed in Syria. See de Luce, 2015.
} 


\section{Israel's Objectives in Syria}

Israel has several principal objectives in the Syria conflict, including minimizing Iranian and Russian influence in Syria, blocking the transfer of advanced weapons to Hezbollah, preventing Syria from posing a credible military threat to Israel or permitting Iran to do so, undermining the legitimacy of Syria's claims to the Golan Heights, and preventing Sunni militants from establishing infrastructure or operational bases along Israel's border. However, Israel has little ability to influence events on the ground in Syria, giving it few tools for advancing its goals directly.

In the long run, Israel would like to see Syria led by a moderate central government that controls its territory, resists Iranian interference, and yet is too weak to threaten Israel militarily. However, Israel's preferred outcome is highly doubtful given the multiplicity of actors in the Syrian conflict; the Assad regime's reliance on Iran; and the likelihood that, even if a peace agreement is reached, the country will be divided into multiple spheres of influence with a weakened central authority. Israel would find unpalatable both of the most likely "resolutions" to the conflict: the re-establishment of territorial control by an Assad government now even more dominated by and indebted to Iran or the disintegration of the country into fiefdoms controlled by a variety of Sunni extremist groups and Iranian proxies. Thus, continued conflict in Syria-a situation in which Sunni extremists and Iranian proxies continue to focus their fire on each other rather than on Israel_might be the most advantageous outcome for Israel. ${ }^{\text {iv }}$

\footnotetext{
iv As British writer Ben Judah argues, "Israel welcomes chaos on its borders" because it is less threatened by "an ethnic patchwork" of enclaves inhabited by homogenous groups (Druze, Kurds, Shi'a, and Sunnis) than by the militarized states created by the 1916 Sykes-Picot Agreement (a secret agreement between
}

[C]ontinued conflict in Syria-a situation in which Sunni extremists and Iranian proxies continue to focus their fire on each other rather than on Israel-might be the most advantageous outcome for Israel.

In the rest of this section, we describe Israel's five main objectives in this conflict.

\section{Objective 1: Contain Iran and Prevent Iranian Transfers of Weapons to Hezbollah}

First and foremost, because Israel sees Iran (particularly if it were to develop or acquire nuclear weapons) as its most significant existential threat, ${ }^{6}$ the Israeli government seeks to constrain Tehran's ability to operate freely in Syria, which is critical to Iran's ability to pressure Israel. Describing Syria's strategic importance to Iran, Michael Oren, then Israel's ambassador to the United States, stated in 2013 that "the greatest danger to Israel is by the strategic arc that extends from Tehran, to Damascus to Beirut. And we saw the Assad regime as the keystone in that arc."7 Israel has little ability to constrain Iran's freedom of action in Syria, however, other than to attack convoys that are transferring weapons to Hezbollah and to bolster its defenses on the Israeli side of the Golan Heights.

As Netanyahu told Putin in September 2015, Tehran uses Syrian territory to threaten Israel's security in two critical ways. First, Iran uses its freedom of maneuver in Syria to provide advanced

the United Kingdom and France about control of territory in southwestern Asia; “Sykes-Picot Agreement," 2009). See Judah, 2016. 
arms and materiel to Hezbollah; ${ }^{8}$ second, Iran's greatly expanded military presence in Syria might allow it to create a new military front on the Golan Heights. To protect Israel's interests, Maj. Gen. (res.) Yaakov Amidror wrote in October 2015, Israel must address both threats by preventing "game-changing weapons, be they Iranian or Russian, from falling into Hezbollah's hands, and preventing Iran from forming a base of operations from which it could attack Israel." 9

As to the first threat, Israel has long viewed with great concern Iran's use of Syrian territory to transfer rockets, weapons, and funding to Hezbollah, aid that enables Hezbollah to threaten Israel from its base in southern Lebanon. In October 2012 and April 2013, Netanyahu stated that Israel would not allow sophisticated weapons - such as Russian anti-aircraft missiles or chemical munitions - to fall into the hands of Hezbollah or al Qaedaaffiliated extremist groups, such as the al-Nusra Front. ${ }^{10}$ Netanyahu repeated this pledge as recently as September 2015, when, in a press conference alongside Putin, he stated, "Israel is constantly working to prevent the transfer of advanced and deadly weaponry from Syrian territory to Hezbollah."11 Elaborating in his October 2015 speech to the United Nations (UN) General Assembly, Netanyahu claimed,

Iran's proxy Hezbollah smuggled into Lebanon SA-22 missiles to down our planes, and [Russian-made] Yakhont cruise missiles to sink our ships. Iran supplied Hezbollah with precision-guided surface-to-surface missiles and attack drones so it can accurately hit any target in Israel. ${ }^{12}$

Iran's capacity to project influence in the Levant and threaten Israel is dependent on its continued ability to move money, weapons, and materiel through Syria to Hezbollah. The group's ability to attack northern Israeli cities with Iranian-provided rockets both enables Tehran to pressure Israel and serves as a deterrent against an Israeli strike on Iran's nuclear facilities. Continued Iranian support keeps Hezbollah relevant, enables it to provide social services and maintain support in southern Lebanon, and prevents it from being surrounded by hostile forces-Lebanese Sunnis and Christians to the north, Sunni militias in Syria to the east, and Israel to the south. As Israeli journalist Ben Caspit notes, "If Syria were to fall, Iran would be isolated and Hezbollah neutralized."13

The second threat, that of a new military front along the Golan, could stretch Israel's military further and endanger Israeli civilians living in the region. Israel—which already has to worry about threats emanating from Gaza, the West Bank, and southern Lebanon-does not want to face Iranian troops on a military front along the Israeli-Syrian border. Iran and Hezbollah have undertaken operations in southern Syria that have enabled them to establish a military infrastructure and to deploy fighters close to the frontier. ${ }^{14}$ Access to the Syrian side of the Golan Heights, Netanyahu asserted in his 2015 UN General Assembly speech, has enabled Iran and Hezbollah to launch attacks into Israel. ${ }^{15}$ Iran

\section{Israel has little ability to constrain Iran's freedom of action in Syria . . . other than to attack convoys that are transferring weapons to Hezbollah and to bolster its defenses on the Israeli side of the Golan Heights.}


If Russian support for [Bashar al-]Assad enables the regime to gain ground ... it could facilitate increased Iranian influence in Syria and thus pose a strategic threat to Israel.

operates so freely in the Syrian Golan, Israeli researcher Eyal Zisser has argued, "the [Islamic Revolutionary Guard Corps] is already acting as if they own Syria." ${ }^{16}$ To preserve its access to Syrian territory, Iran has gone to great effort to prop up the Assad regime; it has deployed thousands of Islamic Revolutionary Guard Corps fighters, provided weapons to Syrian forces, and pressured Hezbollah to move thousands of its own fighters into Syria.

Hezbollah's involvement in the Syrian war on Iran's behalf has stretched the group's capabilities and could, in the long term, work to Israel's advantage. Hezbollah has taken extensive casualties in Syria and has been forced to send reinforcements from Lebanon to replenish its forces, ${ }^{17}$ reportedly lowering recruits' minimum age to meet the demand. ${ }^{18}$ The group's legitimacy — which has always been based on defending Lebanon from the so-called Zionist entity - has been significantly undermined by its decision to send thousands of Lebanese to fight and die in Syria ${ }^{19}$ and by the fact that its involvement in Syria has inspired Sunni militias fighting it in Syria to launch attacks on its home turf in Lebanon's Beka'a Valley. ${ }^{20}$ When the dust settles in Syria (or even beforehand), Hezbollah could emerge as a weakened force in Lebanon with a reduced ability to threaten Israel militarily.
Objective 2: Minimize Russian Political and Military Influence Israel's second objective is to prevent Russia from establishing a permanent military presence in Syria (beyond its long-established naval base in the port city of Tartus), avoiding conflict between Israeli and Russian forces operating in (or over) Syria, and to minimize Russia's ability to bolster Iran's position by providing gamechanging support for the Assad regime. Russia hopes to bolster the position of the Assad regime to ensure that Moscow can continue to maintain a naval presence on the Syrian coast. To the extent that Russian military assistance keeps Assad afloat, it helps to extend the conflict, which keeps Iranian and Hezbollah fighters focused on gaining ground in Syria. If Russian support for Assad enables the regime to gain ground, however, it could facilitate increased Iranian influence in Syria and thus pose a strategic threat to Israel.

Russia's involvement in Syria poses four obstacles to Israel.

First, Israel is concerned that Russia will become a long-term political protector and military patron of a victorious Assad regime backed squarely by Iran and Hezbollah—a "Shiite axis of evil" that Israel sees as its principal regional adversaries. Thus, according to Israeli journalist Ben Caspit, "Putin's efforts to tilt the balance in the Syrian battlefield together with the Iranians comes at the expense of Israel's security needs" ${ }^{21}$ because they enable Iran and its proxies to maintain their influence and their presence in the region, which would expand significantly if Assad were to emerge from the conflict with a strengthened position over large portions of Syrian territory. In one clear example of this shift, Russia's recent decision to provide Iran with S-300 air defense systems-a sale concluded in 2007 but later suspended as tensions over Tehran's nuclear program escalated—gives Iran much greater freedom to operate in 
Syria; if the Iranian regime is more confident about its ability to defend against an Israeli air strike on its territory, it can act more boldly in the Levant without fear of significant Israeli retaliation. ${ }^{22}$

Israel has no real ability to affect Russia's decision to support Assad and Tehran, which Moscow is undertaking to increase its influence and access in both Syria and Iran. Should Russian support to the Syrian government merely enable a stalemate rather than a newly empowered Assad regime, it could end up benefiting Israel; if Syrian, Iranian, and Hezbollah forces remain tied up in a long-term struggle for Syria, they are less able to threaten Israel directly from entrenched positions in Syrian territory.

Second, and more concretely, Israel does not want Hezbollah to get Russian weapons that Moscow provides to the Syrian Army. In the past, Russia has sold Syria Yakhont anti-ship cruise missiles, P-800 and SA-17 surface-to-air missiles (which can also threaten Israeli ships in the Mediterranean), anti-tank weapons, and other weapons, ${ }^{23}$ which Israel claims the Syrian government has subsequently transferred to Hezbollah. ${ }^{24, v}$ When Netanyahu traveled to Moscow in September 2015, soon after Russia deployed additional forces to Syria, he sought to obtain from his Russian counterparts a commitment to prevent the Syrian military from transferring additional Russian weapons to Hezbollah. ${ }^{25}$

Third, the presence of Russian forces hinders Israel's freedom of action in Syria. Israel has occasionally bombed convoys in Syrian territory that it believed were transferring weapons to Hezbollah or otherwise posed a direct threat to Israeli security. Israel's ability to

\footnotetext{
v See also Netanyahu's allegation in his 2015 UN General Assembly speech, cited earlier, that "Hezbollah smuggled into Lebanon ... . [Russian-made] Yakhont cruise missiles to sink our ships" (Prime Minister's Office, 2015c).
}

\section{Russia's troop deployment creates the potential for direct conflict-either deliberate or unintended-between Russian and Israeli} forces.

do so in the future, however, could be constrained by the presence of Russian air defense systems and combat aircraft, which could threaten Israeli pilots undertaking such missions. Indeed, Netanyahu's principal objective for his meeting with Putin in September was reportedly to ensure that Israel could maintain its ability to address near-term tactical threats from Iranian and Hezbollah forces in Syria. ${ }^{26}$

Fourth, Russia's troop deployment creates the potential for direct conflict - either deliberate or unintended-between Russian and Israeli forces. Russian fighter jets could challenge Israeli aircraft on missions over Syria; Russian air defense assets could shoot down Israeli planes; or Israeli bombing could inadvertently cause Russian casualties on the ground. This is not a theoretical possibility; on November 24, 2015, Turkish warplanes shot down a Russian Su-24 fighter jet flying near (or, as Turkey alleged, across) the Turkish border. ${ }^{27}$ In an effort to preserve its military options while minimizing the likelihood of such mishaps, Israel is working with Russia at a technical level to deconflict air and naval operations. Netanyahu's September visit to Russia resulted in an agreement to "coordinate air, naval, and the electromagnetic arenas," 28 which Netanyahu described as "a joint mechanism for preventing misunderstandings between our forces." ${ }^{29}$ In all likelihood, such a mechanism would consist of ways to identify each other's aircraft; alert each other to nearby operations; and deconflict naval opera- 
tions off the Syrian coast, where Russia has a naval base at Tartus. ${ }^{30}$ If Israel and Russia do implement an effective mechanism to deconflict military operations, Russia's deployment might not limit Israel's ability to operate freely in Syrian airspace, although Israeli pilots would need to remain alert to the possibility of an accidental confrontation or an inadvertent bombing that affects Russian troops on the ground. ${ }^{31}$

\section{Objective 3: Promote a Weak Assad Regime}

Israel's third objective is to ensure that the Assad regime remains weak enough that it cannot threaten Israel directly or allow Iranian and Hezbollah forces to operate freely, particularly along the Israeli-Syrian border-a difficult balance to strike. Because Israel sees Iranian influence in the region as the greatest threat to its security, and because Assad is the key enabler of Iran's freedom of action, Israel views Assad's continued rule as a component of the Iranian threat. A decisive Assad victory would enable Iran and Hezbollah to continue operating in the region with impunity. It is no coincidence that all of Israel's kinetic strikes on Syrian territory have targeted Syrian regime facilities and Syria's Iranian and

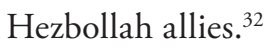

Israel does not, however, want to promote the collapse of the Assad regime, which could lead to a free-for-all in which extremists—-when they are not busy fighting each other-could turn their attention toward Israel, especially if one extremist faction were able to capture remaining stocks of Syrian chemical weapons. Such a security vacuum could lead to cross-border skirmishes or attacks on Israeli territory to which Israel feels compelled to respond militarily. If cross-border violence were to lead the UN peacekeeping mission in the Golan (the UN Disengagement
Observer Force) to withdraw — as it reportedly considered doing after Syrian rebel groups captured 20 peacekeepers in 2013Israel might be more likely to launch pre-emptive strikes in Syrian territory. ${ }^{33}$

If Assad were to fall, a single Syrian group or coalitionperhaps ISIS, or perhaps a group supported by an outside power, such as Russia, Turkey, or even the United States-could consolidate control over a large portion of Syrian territory. After doing so, such an entity could - even in defiance of its foreign patronsactively seek a conflict with Israel as a means of establishing its legitimacy in the broader Arab or Muslim world. In such a scenario, Assad's overthrow could lead to a small, Iranian-dominated Alawite territorial enclave and a hostile new Syrian regime-a possible double threat that could require Israel to continue taking action against weapon transfers to Hezbollah while also defending against cross-border rocket barrages, infiltration of fighters, and terrorist attacks in the Golan.

For Israel, there is therefore some logic to preferring the survival of a weakened devil it knows to the uncertainty of the emergence of a devil it does not. Assad's conventional armed forces do not pose a military threat to Israel, even with assistance from Iran and Russia, and Assad has proven to be both predictable and deterrable in ways that Sunni jihadist groups are not. ${ }^{34}$ A lingering

Israel does not . . . want to promote the collapse of the Assad regime, which could lead to a free-for-all in which extremistswhen they are not busy fighting each othercould turn their attention toward Israel. 


\section{A lingering stalemate-a situation in which Assad survives in Damascus but has limited presence in or influence over other parts of the country, particularly in the south-could enable a weakened Assad to keep a lid on instability without posing much of a threat to Israel.}

stalemate-a situation in which Assad survives in Damascus but has limited presence in or influence over other parts of the country, particularly in the south-could enable a weakened Assad to keep a lid on instability without posing much of a threat to Israel. In such a case, Iran would have only an increasingly tenuous foothold in the Levant and would likely focus its efforts on bolstering its Syrian ally rather than on threatening Israel.

\section{Objective 4: Delegitimize Syrian Claims to the Golan Heights} Israel's fourth objective-one that requires it to take little, if any, action-is to undermine the legitimacy of Syria's claim to sovereignty over the Israeli portion of the Golan Heights. The ongoing Syrian civil war, combined with Assad's increasing dependence on Tehran for his political survival, has made it impossible for Israel to conclude a peace treaty with Syria. Such a treaty seemed tantalizingly feasible in 2011, according to former State Department special coordinator for regional affairs in the Office of the Special Envoy for Middle East Peace Frederic C. Hof. ${ }^{35}$ At that time, popular protests inspired by the Arab Spring uprisings throughout the region marked the first significant challenge to the Assad regime.
If Assad had been able to reclaim the Golan Heights from Israelthrough an agreement that would presumably have required Syrian guarantees of security along the border and the elimination of Iranian influence and Hezbollah's access-Assad would have been able to strengthen his position in the face of calls for greater democratization. However, the government's crackdown on the protestswhich led opposition groups to organize, arm, and rebel—sparked the beginning of the civil war and brought a halt to negotiations regarding the Golan. After military setbacks forced Assad to withdraw 20,000 Syrian troops from the Golan to defend Damascus in 2013, leading to a security vacuum filled by warring Sunni militias and Iranian-backed Shi'a fighters, Assad lost the ability to offer Israel a credible promise of a secure border. ${ }^{36}$ Moreover, Assad's reliance on Iranian and Hezbollah fighters prevents him from being able to expel Iran from the country, as Israel would demand.

The Syrian regime's inability to exert control over its territory means that there is no effective government in Damascus to which Israel could relinquish the Golani land it captured in 1967.77 Officials on all sides of the Israeli political spectrum—ranging from right-wingers motivated by territorial nationalism to leftists who recognize that Israel cannot return the Golan in the current climate-are promoting steps to expand Israel's presence in the Golan by building additional housing, promoting tourism, and investing in infrastructure and industry. ${ }^{38}$ Thus, the mere continuation of the Syrian conflict has undermined Syria's claim to the Golan and strengthened Israel's hold on it. 


\section{Objective 5: Constrain Sunni Militants but Not Necessarily} ISIS

Israel is not particularly concerned about the near-term threat posed by the collection of Sunni extremists in Syria, such as ISIS and the al-Nusra Front, which are preoccupied with fighting the Assad regime and each other. As retired Israeli Maj. Gen. Yaakov Amidror wrote for the Begin-Sadat Center for Strategic Studies, "The radical Sunni groups on the northern and southern borders pose no immediate threat, and while they may deliver unpleasant surprises, they have more immediate enemies to fight." 39 That said, Israel would like to prevent Sunni militants present in the Syrian Golan from establishing infrastructure and ensconcing themselves in the region, principally to prevent violent extremists from establishing bases of operations along its border. ${ }^{40}$

Israel does see the potential for Sunni jihadi groups operating in Syria to destabilize Israel's neighbors - particularly Jordan and Egypt - as a possible long-term threat. In January 2016, Syrian forces backed by Russian airpower attacked ISIS and ISIS-aligned opposition fighters in southwest Syria; ${ }^{41}$ continued successful advances could drive them to flee across the border into Jordan. ${ }^{42}$ Several thousand Jordanians have joined ISIS, and the risk that they could bring their military training and extremist ideology home to destabilize Jordan is of great concern to Israel. ${ }^{43}$ However, Israel has few tools to address extremists' ability to undermine the governments of neighboring countries other than to share intelligence on jihadis' activities and to continue existing security and law enforcement cooperation. ${ }^{44}$

Interestingly, given the intense-and growing — concern in the United States and Europe about the strength of ISIS in Syria,

\section{[T] he Israeli government does not see ISIS as posing a strategic threat to Israel's security.}

the Israeli government does not see ISIS as posing a strategic threat to Israel's security. Israel is modestly concerned about the group's territorial encroachments on its neighbors (particularly in the Sinai and in the Syrian Golan), the possibility that it might destabilize its neighbors, and the prospects that it might target Israel in the future. ${ }^{45}$ But, although ISIS has attacked Shi'a in Hezbollah-dominated areas of Lebanon, raising the possibility of sectarian conflict on Israel's northern border, the spread of fighting to southern Lebanon has a potential silver lining for Israel in that it could keep Hezbollah busy fighting ISIS and thus unable to focus attacks on Israel. ${ }^{46}$ Even if ISIS were to gain control of territory along Israel's border in either Syria or Lebanon-a potential worstcase scenario-Israel would be relatively free to take military action against the group given the near-universal international opposition to it. ${ }^{47}$

Israel's principal ISIS-related goal is not to fight the group but rather to make sure the West does not partner with Iran (or even tolerate Iran's nuclear ambitions or regional influence) in an effort to fight ISIS jointly. As retired Israeli Brig. Gen. Michael Herzog writes, the West must

not give Iran a pass. The war against [ISIS] should be fought with a long-term view for the future of the region, including a clear eyed view of the threat posed by Iran and its agenda for regional hegemony based on anti-Western values, Shi'a dominance, and nuclear capabilities. The desire to secure a nuclear deal with Iran and join hands in fighting [ISIS] should not obscure these concerns. ${ }^{48}$ 


\section{By responding militarily to cross-border violence, Israel makes clear that it takes every attack on its territory seriously and that perpetrators will suffer consequences.}

\section{Israel's Actions to Date}

Because Israel has neither a firm preferred outcome for Syria nor the ability to shape events on the ground there, it has done little to advance its objectives other than occasionally attack precise Syrian, Iranian, and Hezbollah targets that pose an immediate threat to Israel; clandestinely engage communities on the Syrian side of the border; and diplomatically engage Russia_one of the few entities with influence in Syria with which it can deal. (That said, Israel opposes an expansion of Russia's military presence there and fears that game-changing Russian military aid to the Assad regime could enable Iran to expand its own access and influence in Syrian territory). As a result, the actions Israel has taken to date have been mostly defensive (if occasionally pre-emptive) and, at times, subtle.

\section{Defend Territory and Respond to Cross-Border Strikes}

First and foremost, Israel has acted occasionally to defend its territory, consistent with Netanyahu's statement at the 2015 UN General Assembly session that "Israel will continue to respond forcefully to any attacks against it from Syria." ${ }^{49}$ In March and April 2015, for example, Israel killed militants placing bombs on the Israeli side of the Golan fence; ${ }^{50}$ in September 2014, Israel used Patriot air defense missiles to shoot down a Syrian Air Force jet that crossed into Israeli airspace. ${ }^{51}$

Since late $2012,{ }^{52}$ Israel has also responded in kind to crossborder artillery barrages into its territory, even when those incidents are inadvertent—-many rockets landing in Israel, for example, are likely to be stray rockets launched in fighting between Syrian Army units and Sunni rebel forces - and even when they cause no damage..$^{53}$ In the wake of one such incident, which provoked an Israeli counter-strike, Minister of Defense Moshe Ya'alon stated in October 2015, "the State of Israel has no intention of ignoring such incidents." ${ }^{54}$ By responding militarily to cross-border violence, Israel makes clear that it takes every attack on its territory seriously and that perpetrators will suffer consequences. Israeli officials have stated that the Syrian Army is responsible for such violations of Israeli sovereignty, whether intentional or not. ${ }^{55}$ As a result-and in part because Israel has no interest in starting conflicts with individual jihadist groups that might also have been involved in the original artillery exchanges-Israel has aimed its retaliatory strikes at Syrian military facilities.

\section{Bomb Hezbollah Operatives and Weapon Transfers}

Secondly, Israel has taken strong actions to prevent Iran from transferring advanced weapons to Hezbollah in Syria and to undermine Iranian and Hezbollah efforts to establish a physical infrastructure in Syria - the makings of "an additional terrorist front," as Netanyahu warned the Knesset in October $2015^{56}$ — that could threaten Israel. Thus, Israeli planes have launched strikes inside Syria, killing Hezbollah fighters who were involved in attacks on Israel ${ }^{57}$ and bombing shipments of Russian- and Iranian-made missiles being transferred to Hezbollah in January, May, and November 2013. ${ }^{58}$ Some of the targets have included Syrian government and military 
bases, including the Damascus airport, a Syrian missile base in Latakia, and a reputed Syrian chemical-weapon facility in Damascus. ${ }^{59}$

Although Israel has bombed Iranian weapon caches destined for Hezbollah, it is not eager to risk escalating tensions with Iran by attacking Iranian personnel in Syria. That said, a January 2015 Israeli helicopter attack on a Hezbollah convoy in the Syrian Golan killed a senior Iranian general and possibly six Iranian soldiers, although it is not clear whether Israel was aware of the Iranians' presence in the convoy. ${ }^{60}$

Israel's ability to mount pre-emptive strikes on Iranian, Syrian government, and Hezbollah positions is likely to be limited by Russia’s deployment of forces to Syria; Russia is supporting the Syrian government and thus would generally oppose Israeli attacks on Syrian forces and their Iranian and Hezbollah allies. ${ }^{61}$ Indeed, just a week after Putin and Netanyahu met to discuss the conflict, Russia expressed opposition to Israel's September 27 air strikes on a Syrian military facility, although it is unclear whether such a statement was simply rhetorical or whether Moscow would take some action to deter or respond to future Israeli attacks. ${ }^{62}$ Unless Israel and Moscow can deconflict military actions in Syria—or unless Putin gave Netanyahu reassurances that Russia would tolerate Israeli attacks on weapon transfers to Hezbollah-Israel might, despite

Israel has subtly reached out to civilians and moderate anti-regime fighters in Syria in an effort to keep the border area inhospitable to forces from the Syrian government, Iran, and Hezbollah. statements to the contrary, be forced to act more conservatively to avoid provoking Moscow or inadvertently striking Russian forces.

\section{Provide Clandestine Support to Anti-Regime Syrians}

Third, Israel has subtly reached out to civilians and moderate antiregime fighters in Syria in an effort to keep the border area inhospitable to forces from the Syrian government, Iran, and Hezbollah. By maintaining good relations with such audiences-through the provision of humanitarian aid to Syrian civilians, ${ }^{63}$ for example, and by treating some wounded civilians and anti-Assad fighters at Israeli hospitals ${ }^{64}$ - Israel hopes to keep pro-regime fighters out of the area entirely or, at the very least, make it harder for them to operate freely. ${ }^{65}$ (It is possible as well that Israel is using such humanitarian outreach to gather intelligence about the situation on the Syrian side of the border.)

Israel also fears that violence against Druze civilians in Syria will lead to a refugee crisis, with thousands of Syrian Druze seeking safe haven in Druze communities on the Israeli side of the border. To prevent such a predicament from materializing, Israel has purportedly cautioned Sunni rebels in Syria not to attack Druze communities, and-in comments interpreted as referring to Syrian Druze-Israel Defense Forces (IDF) chief of staff Lt.-Gen. Gadi Eisenkot testified to the Knesset in June 2015 that, if a large number of refugees were to flee toward the Israeli border to escape fighting, Israel would "do what is needed to prevent a massacre.”66 Toward this end, Israel encouraged the United States to provide assistance to Syrian Druze, and it has reportedly considered the establishment-perhaps under the auspices of the UN or the International Committee of the Red Cross - of a humanitarian corridor or safe zone for Syrian Druze inside Syrian territory. ${ }^{67}$ 
Such comments and endeavors might be intended for Israel's sizable Druze population as much as for anyone else. Indeed, to reassure Israeli Druze, Israeli Air Force (IAF) commander Maj. Gen. Amir Eshel told community leaders that "the [Israeli] alliance with the Druze people does not stop at the border." ${ }^{68}$ Israeli Druze are seen as a potential conduit to their brethren on the Syrian side of the border, who-despite generally being pro-Assad and hostile to Israel ${ }^{69}$ - might be able to help keep the border area quiet. ${ }^{70}$ Israeli Druze have protested to raise attention to the plight of their Syrian co-religionists, and they would certainly advocate for the admission of Syrian Druze refugees into the country. Many Israelis might be wary of the government's efforts to mollify the Druze, whom many Israelis view as a potential disloyal fifth column.

Although such concerns are likely overblown, they are not unthinkable; in March 2015, the government arrested an Israeli Druze soldier for providing sensitive information about the IDF's operations in the Golan to an Israeli Druze civilian, who, in turn, passed it to the Syrian government. ${ }^{71}$

\section{Engage Moscow}

Fourth, Israel has opened a dialogue with Russia to discuss both strategic and tactical interests in Syria. Russia's military involvement in Syria on behalf of the Assad regime makes it extremely helpful to-perhaps even essential for-Iran's ability to achieve its goals in the region. Israel hopes that Moscow can be encouraged to use its newfound leverage over Tehran to block Iranian actions that directly threaten Israel. Israel also hopes to deconflict its military operations with Russia to prevent an inadvertent conflict and to preserve its freedom of action, as discussed above.
Israel also fears that violence against Druze civilians in Syria will lead to a refugee crisis, with thousands of Syrian Druze seeking safe haven in Druze communities on the Israeli side of the border.

Israel's outreach to Russia serves another purpose for the Israeli government. At a time of highly strained U.S.-Israeli relations, these bilateral discussions-particularly the fact that they have been held at the head-of-state level—send a signal to Washington that Israel has other partners to which it can turn. Similarly, from Putin's perspective, dialogue with Israel on matters related to Iran and Middle East security demonstrates that Russia remains influential with close U.S. allies regarding issues that greatly concern the United States.

\section{Israel's Options}

Israel's options for affecting the situation in Syria are extremely limited. It has minimal ability to undermine Iranian influence in areas along its border and no ability to affect Iran's activities farther afield. Other than by bombing Hezbollah operatives, weapon caches, or shipments of materiel destined for the groupsomething it has done to date only when such actions head off a direct threat—it has little capacity to degrade Hezbollah capabilities. Short of direct military intervention or the provision of lethal support to Syrian rebel groups-actions that there is no indication Israel desires to undertake-Israel cannot affect the Assad regime's ability to survive, nor can it influence what groups or individuals might succeed Assad. 
Israel might not see much benefit in taking sides in Syria's civil war. Although Israel is certainly no friend of Assad, neither is it fond of the rebels who might rule Syrian territory after his demise, with uncertain objectives of their own. As Israeli journalist Jacky Hugi has written, "These are ad-hoc militias whose purpose is not clear and who are subject to influence or occupation by forces stronger than they are."72 An unnamed IDF officer captured Israel's lose-lose quandary more bluntly in a statement to the online news outlet Al-Monitor:

Either way, the result would be bad. A victory of a Russianbacked radical axis that consists of Iran-Syria-Hezbollah is not a positive thing for Israel. But on the other hand, the concentration of all the global jihad madmen in Damascus and the Golan Heights is also a disconcerting development. ${ }^{73}$

Interestingly, aggressive military involvement would not necessarily put Israel in a better position. Israel could undertake a robust bombing campaign that targets Hezbollah and Iranian forces in Syria. However, it is not clear how such an effort would benefit Israel. An all-out concerted military campaign against Iran and its proxies would risk a direct war between Israel and Iran thatpublic rhetoric to the contrary - neither country's leadership would want. Occasional IAF sorties could eliminate near-term tactical threats, but they would not significantly degrade Iran's or Hezbollah's long-term ability to operate in Syria as long as the Alawites remain in power. A ground invasion to establish a territorial buffer zone in the Syrian Golan-even to establish a humanitarian corridor for refugees - would be counterproductive. A seizure of Syrian territory would make Israel a focal point of the Syrian conflict and, without a UN Security Council authorization, would be highly controversial internationally. Indeed, sustained military action in any form would put Israel squarely in the crosshairs of many of the actors fighting in Syria and others across the Arab and Muslim worlds.

Contributing to the overthrow of the Assad regime in order to expel Iran would, as noted by the unnamed IDF officer cited above, open a Pandora's box of unpredictable jihadi groups - a prospect that brings to mind former Director of Central Intelligence R. James Woolsey's observation about the fall of the Soviet Union: "Yes, we have slain a large dragon, but we live now in a jungle filled with a bewildering variety of poisonous snakes. And in many ways the dragon was easier to keep track of." ${ }^{74}$

The IDF can advance Israel's goals most effectively by using force as a tactical tool that eliminates specific real-time threatsnot as a strategic tool to change the regional environment. As a result, Israeli military engagement in Syria is expected to remain sporadic and limited to occasional strikes to prevent attacks on Israeli territory or immediate transfers of weapons to Hezbollah. Such an approach would prevent Israel from being drawn into a

\section{Short of direct military intervention or the provision of lethal support to Syrian rebel groups- actions that there is no indication Israel desires to undertake-Israel cannot affect the Assad regime's ability to survive, nor can it influence what groups or individuals might succeed Assad.}


civil war whose course it cannot meaningfully affect and prevent unintended clashes with Iranian or Russian forces. It could change the means by which it engages Hezbollah targets—-such as by waiting to attack convoys moving weapons until they enter Lebanese territory-but such shifts in tactics would not signal a change in Israel's overall approach to its interests in Syria.

Given Russia's military presence in Syria-which includes batteries of advanced S-400 air defense systems ${ }^{75}$ - Israel cannot engage in frequent air strikes on targets in Syria without some form of operational coordination or deconfliction with Russia. A downed pilot would be a significant crisis for Israel, which makes the rescue of Israeli prisoners of war and hostages a top national priority-particularly if the pilot were captured, whether dead or alive, by jihadi groups or by forces aligned with Iran. Netanyahu's visit to Moscow resulted in an agreement to share some degree of information about military operations, ${ }^{76}$ which will likely avert inadvertent incidents; however, to maintain true freedom of action, Israel would need to reach a strategic understanding with Moscow about what it would be trying to accomplish through attacks on Russian-aligned forces in Syria and about what Russia would allow Israel to do without interference. Given that most of Israel's allies and partners have seen their relations with Moscow deteriorate in

The IDF can advance Israel's goals most effectively by using force as a tactical tool that eliminates specific real-time threatsnot as a strategic tool to change the regional environment.

\section{Israel should encourage Russia to press its Syrian client to reduce Iranian influence and activities near Israel's border.}

the past few years, Israel would likely have to reach a diplomatic accommodation with Russia by itself.

In addition to negotiating greater freedom to maneuver for the IAF, Israel should encourage Russia to press its Syrian client to reduce Iranian influence and activities near Israel's border. Russia's interest is not to ensure that Hezbollah has a constant supply of Iranian weapons with which to threaten Israel but rather to expand its own influence in Syria - a goal that makes Iran, the other major power broker in the country, somewhat of a competitor to Moscow. It is not clear, however, whether Russia has the ability to box Iran out: Assad needs assistance from Moscow and Tehran (and Hezbollah) to stay in power.

At the same time as it conducts occasional strikes on targets in Syria that pose imminent threats to Israel, the Israeli government will likely continue, and perhaps expand, its efforts to "soften" the Syrian Golan to make it less hospitable to Iranian forces and proxies. Whether undertaken by Israel or by international aid organizations, the provision of humanitarian relief, medical care, and other basic supplies to villages in the Syrian Golan could encourage these populations to resist the influence or oppose the presence of both Hezbollah militants and Sunni extremists. Such assistance could also help avoid a refugee crisis by encouraging Syrian Golan residents to remain where they are rather than attempt to cross the border into Israel. 
Unless Syria collapses into a chaotic free-for-all that appears likely to lead to extended cross-border violence stemming from southern Syria, Israel is unlikely to create a "Druze safe zone" on the Syrian side of the border, even though an effort that prevents massacres of Syria's 700,000 Druze would keep hostile fighters away from the Israeli border, deter recruitment of border residents by extremist groups, prevent a refugee crisis, and placate Israel's own Druze population. Such a humanitarian corridor would be difficult to implement without deploying Israeli troops on the ground or arming Syrian Druze for self-protection. Either approach would make Israel a clear party to the conflict and thus a target for retaliation; moreover, given that Syria's Druze have generally been loyal to the Assad regime, Israel will not want to arm a sect that might subsequently follow orders from Damascus to cause cross-border turmoil. If Sunni militias seem poised to extend their control to the Syrian Golan, however, Israel might work more proactively — though clandestinely — with Syrian Druze to bring stability to the Syrian side of the border region. ${ }^{77}$

Should Hezbollah be significantly weakened by its participation in an extended Syrian conflict, Israel might decide that the time is ripe to try to deliver a crushing blow to the group in Leba-

[E]ven though the Syria conflict has depleted Hezbollah's cadre of fighters and undermined its ideological legitimacy, the group continues to enjoy popular support among Lebanese Shi'a and would likely see a surge in recruits in response to an Israeli strike. non. But even though the Syria conflict has depleted Hezbollah's cadre of fighters and undermined its ideological legitimacy, the group continues to enjoy popular support among Lebanese Shi'a and would likely see a surge in recruits in response to an Israeli strike. Israel would be unlikely to take such a step unless Iran were to lose its access to Syrian territory and thus, along with it, its ability to provide Hezbollah with weapons to respond to Israeli attacks. Even then, Israel would have to be willing to withstand a significant assault from Hezbollah's sizable existing arsenal of rockets, which could cause extensive civilian casualties in Israel.

The international nuclear agreement with Iran, the Joint Comprehensive Plan of Action (JCPOA) ${ }^{78}$ is unlikely to affect Israel's approach to the armed conflict in Syria. That said, it will likely give additional momentum to Israel's strategy of ensuring that Iran remains internationally isolated; it will oppose any Western diplomatic engagement of Iran or apparent tolerance of Iranian adventurism throughout the region, including in Syria, in an effort to bolster Iranian moderates or protect the agreement from being undermined by Iranian mischief.

Throughout the nuclear negotiations, Israel mounted an aggressive diplomatic campaign to discredit the deal; it argued that Iran could covertly develop a nuclear weapon and that the unfreezing of Iranian assets and Iran's reintegration into the global economy would fund Iranian assistance to Hezbollah and to the Assad regime, thereby fueling both the Syria conflict and terrorist attacks on Israel. Israel has also been concerned that the West, in its eagerness to see the JCPOA succeed, would tolerate Iran's belligerent behavior in the region, overlook minor failures to comply with the nuclear deal, and treat Iran as a "normal" international actor by engaging it on a variety of political and economic issues. Indeed, 
Israel has also been concerned that the West, in its eagerness to see the [Joint Comprehensive Plan of Action] succeed, would tolerate Iran's belligerent behavior in the region, overlook minor failures to comply with the nuclear deal, and treat Iran as a "normal" international actor by engaging it on a variety of political and economic issues.

since the JCPOA was signed, the United States and European Union have acknowledged that finding a solution to the Syrian conflict will be difficult without Iran and have agreed to include Tehran in Syria talks. ${ }^{79}$

Israel remains deeply distrustful of Iran's nuclear ambitions and is wary that Iran will use the resources provided by sanctions as relief to fund terrorism, increase its military engagement in Syria, and project its influence in the region. Having failed to prevent the agreement, Israel is now pressuring the United States and other JCPOA signatories to implement the accord as aggressively as possible to prevent the possibility that Iran will cheat. ${ }^{80}$ Israel will also attempt to keep Iran isolated and oppose international efforts to normalize diplomatic relations with Iran—such as by including Tehran in Syria peace talks - now that sanctions have been lifted.

\section{Conclusions}

Israel has little ability to affect the strategic situation in Syria. It cannot restrain Iranian behavior in Syria or prevent its forces (or its allies) from operating along Israeli borders, its principal strategic concerns. Russian intervention to prop up the Assad government has facilitated Iran's freedom of action in the region, including its ability to transfer weapons to Hezbollah for the purpose of attacking Israel.
Israel has few good options for intervening in the Syrian conflict, principally because there is no likely outcome that would be more favorable to Israel than the violent status quo. Assad's survival would ensure continued Iranian access; Assad's collapse would likely lead to the Balkanization of the country into a multiplicity of fiefdoms, some of which are likely to be hostile to Israel or permit anti-Israeli activity. Arming Syrian Druze-the group most sympathetic to Israel despite their ties to the Assad regime-would make Israel a party to the conflict and potentially backfire on Israel in the long run. Even direct intervention to establish a humanitarian safe zone in the Syrian Golan would be seen as an Israeli seizure of Arab and Muslim territory, which would make Israel a party to the conflict and a target for retaliation. Continued stalemate in Syria could advance Israel's interests more than any decisive outcome, and no Israeli action is needed to prolong the conflict.

Israel is therefore likely to maintain its current course of proactive self-defense. It will continue to launch air strikes to prevent transfers of weapons to Hezbollah and attacks on Israeli territory, and (principally as a means of deterrence) it will continue to respond to stray rocket-artillery shells that land in Israel. To do so, however, it will have to reach a diplomatic agreement with Moscow to ensure that Israeli aircraft are not shot down and to avoid inadvertent Israeli strikes on Russian positions. If Israel and Russia cannot reach such an agreement, Israel's ability to act as assertively 
and as frequently as it wishes might be constrained. Israel could continue non-lethal outreach to Syrian Druze and other communities in the Syrian Golan, while also encouraging other countries to do the same, in an effort to make these border areas inhospitable to fighters from Iran, Hezbollah, or Sunni jihadist groups who might wish to cause a cross-border incident.

Despite the carnage in Syria and the intense international attention being paid to it, Israel faces bigger threats to its national

\section{Notes}

\section{Page 1}

1 Dekel and Magen, 2015.

\section{Page 2}

2 Kuperwasser, 2015.

3 Lappin, 2015b.

4 Dekel and Magen, 2015.

5 Koplow, 2015.

\section{Page 3}

6 See, for example, Netanyahu's remarks at the 2012 Holocaust Remembrance Day ceremony at Yad Vashem, in which he asserted, "A nuclear-armed Iran is an existential threat of [sic] the State of Israel.” See Prime Minister’s Office, 2012. More recently, Moshe Ya'alon, defense minister of Israel—citing Iran's global terrorism infrastructure, its desire for regional hegemony, and its support for Hezbollah—said in January 2016, "Iran is our main enemy." See "I Prefer ISIS,"” 2016.

\section{Williams, 2013.}

\section{Page 4}

8 Pollack, 2015b.

9 Amidror, 2015b.

${ }^{10}$ R. Jones, 2012b; "Netanyahu Says Israel Ready to Act Against Syrian Rebels," 2013.

${ }^{11}$ Prime Minister's Office, 2015b. security, such as the potential covert continuation of Iran's nuclear program, Iranian assistance to Hamas in the Gaza Strip, and Palestinian unrest in the West Bank and in Israel proper. Unless violence from Syria spills over Israel's borders in a significant way or threatens to do so imminently, Israel is unlikely to have a need or a desire to focus its attention or resources on the Syrian conflict.

12 Prime Minister's Office, 2015c.

${ }^{13}$ Caspit, 2014.

${ }_{14}$ Herzog, 2015b; Ben-Yishai, 2015; Zisser, 2015; "Nasrallah Confirms Hezbollah," 2015.

15 Prime Minister's Office, 2015c.

Page 5

${ }^{16}$ Zisser, 2015.

${ }_{17}$ Morris and Salim, 2015.

18 Naylor, 2014.

19 Wittes, 2015.

${ }^{20}$ Naylor, 2014.

${ }^{21}$ Caspit, 2015c; see also Caspit, 2015b.

Page 6

${ }^{22}$ Federman, 2015.

${ }^{23}$ Gordon and Schmitt, 2013; "Israel to Russia," 2011.

${ }^{24}$ Pollack, 2015b; Gordon and Schmitt, 2013.

${ }^{25}$ Dekel and Magen, 2015.

26 Wittes, 2015.

${ }^{27}$ Naylor and Roth, 2015.

${ }^{28}$ Lappin, 2015a.

${ }^{29}$ Prime Minister's Office, 2015 b. 


\section{Page 7}

30 "Israeli," 2015.

31 Russia's March 14, 2016, announcement that it would withdraw the "main part" of its forces in Syria is unlikely to change the strategic calculus for Assad or for Israel. Because Russia plans to maintain its naval base in Tartus and its air base in government-held Latakia, Moscow could still support regime forces as needed with air strikes and with Russian-made weapons. Israeli Air Force planes undertaking missions over Syria would still need to be mindful of threats posed by Russian combat jets and air defense systems. The risk of inadvertently bombing Russian forces on the ground would still exist, although it would presumably be mitigated somewhat if Russian forces were confined to naval and air bases as opposed to integrated with Syrian regime units. See MacFarquhar and Barnard, 2016.

32 Koplow, 2015; Wittes, 2015.

33 “UN Personnel Abducted on Israel-Syria Border," 2013.

${ }^{34}$ Koplow, 2015.

\section{Page 8}

${ }^{35}$ Hof, 2015.

36 “Israel Worries over Syria’s Golan Pullback," 2013.

${ }^{37}$ Rudoren, 2015.

${ }^{38}$ Rudoren, 2015.

\section{Page 9}

${ }_{39}$ Amidror, 2015a.

${ }^{40}$ Dekel and Magen, 2015.

${ }^{41}$ S. Jones and Solomon, 2016.

42 Segal, 2015.

${ }^{43}$ Peled, 2015.

44 Wittes, 2015.

${ }^{45}$ Herzog, 2015a.

46 Reuters, 2015

${ }^{47}$ Inbar, 2015.

${ }^{48}$ Herzog, 2015a.

\section{Page 10}

49 Prime Minister's Office, 2015c.

${ }^{50}$ Harel and Cohen, 2015.

51 Israel Defense Forces, 2014

52 R. Jones, 2012a, 2012c.

53 “Rockets Hit Russian Embassy Compound in Damascus," 2015.

${ }^{54}$ Lappin, 2015c.

55 "Israel Targets Syria Army Posts After Rockets Hit Golan," 2015; Lappin, 2015c.

56 Prime Minister's Office, 2015d.

57 Times of Israel staff and Davidovich, 2015.

58 Sherwood, 2013.

Page 11

59 Sherwood, 2013; "Report," 2013.

${ }^{60}$ Zitun, 2015; Kais, 2015

${ }^{61}$ Pollack, 2015b.

62 "Putin Said to Be Concerned About Israeli Airstrikes in Syria," 2015.

${ }^{63}$ Several Israeli civil society organizations are providing humanitarian assistance to communities on the Syrian side of the border (Peri, 2015).

${ }^{64}$ Frantzman, 2015.

${ }^{65}$ Ben-Yishai, 2015; see also Prime Minister’s Office, 2015a.

${ }^{66}$ Ahnsaf, 2015; Ginsburg and Beck, 2015; Raydan and Levitt, 2015; Zityun and Raved, 2015.

${ }^{67}$ Ahnsaf, 2015; Ginsburg and Beck, 2015; Raydan and Levitt, 2015.

\section{Page 12}

${ }_{68}^{6}$ Uni, 2015.

${ }^{6}$ Pollack, 2015a.

${ }^{70}$ Caspit, 2015a.

71 “Syria Espionage Case,” 2015. 
Page 13

72 Hugi, 2015.

73 Caspit, 2014.

74 U.S. Senate, 1993 , p. 76

\section{Page 14}

75 MacFarquhar, 2015.

${ }^{76}$ Prime Minister's Office, 2015b.

\section{References}

Ahnsaf, Zalman, "Israel Would Create DMZ for Syrian Refugees," Hamodia, June 16, 2015. As of December 14, 2015:

http://hamodia.com/2015/06/16/israel-would-create-dmz-for-syrian-refugees/

Amidror, Yaakov, "Israeli Strategic Challenges and Opportunities in the New Year," Begin-Sadat Center for Strategic Studies, Perspectives Paper 307, September 16, 2015a. As of December 14, 2015:

http://besacenter.org/perspectives-papers/

israeli-strategic-challenges-and-opportunities-in-the-new-year/

"The Russian-Iranian Gambit in Syria," Begin-Sadat Center for Strategic Studies, Perspectives Paper 308, October 6, 2015b. As of December 14 2015:

http://besacenter.org/perspectives-papers/the-russian-iranian-gambit-in-syria/

Benelux Economic Union, Federal Republic of Germany, and French Republic, Agreement Between the Governments of the States of the Benelux Economic Union, the Federal Republic of Germany and the French Republic on the Gradual Abolition of Checks at Their Common Borders, Schengen, Luxembourg, June 14, 1985. As of April 30, 2016:

http://eur-lex.europa.eu/legal-content/EN/ALL/?uri=CELEX:42000A0922(01)

Ben-Yishai, Ron, "Assad and Hezbollah Are Taking Advantage of Rebels' Weakness," Ynetnews, February 13, 2015. As of December 14, 2015:

http://www.ynetnews.com/articles/0,7340,L-4626144,00.html

Caspit, Ben, "Israeli Security Chiefs Modify Assessment on Syrian War," Al-Monitor, February 11, 2014. As of December 14, 2015:

http://www.al-monitor.com/pulse/originals/2014/02/

syria-war-assad-rebbels-hezbollah-iran-lebanon.html
Page 15

77 Wittes, 2015.

${ }^{78}$ China et al., 2015.

Page 16

79 Torfeh, 2015; Erdbrink, Chan, and Sanger, 2015.

${ }^{80}$ Davis, 2015; see also Kaye and Martini, 2014, p. 9.

"Will Israel Reach Out to Syrian Druze?" Al-Monitor, June 15, 2015a. As of December 14, 2015:

http://www.al-monitor.com/pulse/originals/2015/06/

israel-syria-druze-golan-heights-assad-rebels-civil-war.html

, "Israel Fears Return of Persian Empire," Al-Monitor, September 21, 2015b. As of December 14, 2015:

http://www.al-monitor.com/pulse/originals/2015/09/

israel-fear-persian-empire-iran-shiite-hezbollah-axis-nuke.html

, "Russia, Israeli Jets Share Syrian Skies . . f for Now," Al-Monitor,

November 2, 2015c. As of December 14, 2015:

http://www.al-monitor.com/pulse/originals/2015/11/

lions-israel-russia-vladimir-putin-syria-fire-border.html

China, France, Germany, Russian Federation, United Kingdom, United States, with the High Representative of the European Union for Foreign Affairs and Security Policy, and the Islamic Republic of Iran, Joint Comprehensive Plan of Action, Vienna, July 14, 2015. As of May 1, 2016:

http://www.state.gov/e/eb/tfs/spi/iran/jcpoa/

Dagher, Sam, and Asa Fitch, "Iran Set to Grow Its Role in Syria," Wall Street Journal, October 3, 2015, p. A1.

Davis, Julie Hirschfeld, "Obama and Netanyahu Seek to Move Past Rift over Iran Nuclear Deal," New York Times, November 9, 2015. As of January 29, 2016: http://www.nytimes.com/2015/11/10/world/middleeast/ obama-netanyahu-iran-nuclear-deal.html

Dekel, Udi, and Zvi Magen, "Russian Involvement in Syria: What Has Changed, and the Significance for Israel," Institute for National Security Studies, Insight 752, October 7, 2015. As of December 14, 2015: http://www.inss.org.il/index.aspx?id=4538\&articleid=10699 
de Luce, Dan, "Syrian War Takes Rising Toll on Hezbollah," Foreign Policy, July 9, 2015. As of December 14, 2015:

http://foreignpolicy.com/2015/07/09/syrian-war-takes-rising-toll-on-hezbollah/

Erdbrink, Thomas, Sewell Chan, and David E. Sanger, "After a U.S. Shift, Iran Has a Seat at Talks on War in Syria," New York Times, October 28, 2015. As of January 29, 2016:

http://www.nytimes.com/2015/10/29/world/middleeast/

syria-talks-vienna-iran.html

Federman, Josef, "Amid Regional Turmoil, Israel Courts Russian Tourists," Associated Press, December 3, 2015. As of April 29, 2016: http://bigstory.ap.org/article/370ee5020c764025ba6db066631a6215/ amid-regional-turmoil-israel-courts-russian-tourists

Frantzman, Seth J., "Terra Incognita: Have Israel’s Good Intentions Gone Awry on the Syrian Border?" Jerusalem Post, June 27, 2015. As of December 14, 2015: http://www.jpost.com/Opinion/Terra-Incognita-Have-Israels-good-intentionsgone-awry-on-the-Syrian-border-407330

Ginsburg, Mitch, and Jonathan Beck, "IDF Chief: Army Would Act to Prevent Slaughter of Syrian Refugees," Times of Israel, June 16, 2015. As of December 14, 2015:

http://www.timesofisrael.com/

idf-chief-army-would-act-to-prevent-slaughter-of-syrian-refugees/

Gordon, Michael R., and Eric Schmitt, "Russia Sends More Advanced Missiles to Aid Assad in Syria," New York Times, May 16, 2013. As of December 14, 2015: http://www.nytimes.com/2013/05/17/world/middleeast/ russia-provides-syria-with-advanced-missiles.html

Harel, Amos, and Gili Cohen, "IDF Foils Attempted Terror Attack in Golan, Near Syria Border," Haaretz, April 27, 2015. As of December 14, 2015: http://www.haaretz.com/israel-news/1.653692

Herzog, Michael, Jihad on the Horizon: The ISIL Threat from an Israeli Perspective, Britain Israel Communications and Research Centre, Expert View, March 2015a. As of December 14, 2015:

http://www.washingtoninstitute.org/policy-analysis/view/ jihad-on-the-horizon-the-isil-threat-from-an-israeli-perspective

“Southern Syria: A New Front for Israel?” Washington Institute for Near East Policy, Policywatch 2380, March 2, 2015b. As of December 14, 2015: http://www.washingtoninstitute.org/policy-analysis/view/ southern-syria-a-new-front-for-israel
Hof, Frederic, "I Got Syria So Wrong," Politico Magazine, October 14, 2015. As of December 14, 2015:

http://www.politico.com/magazine/story/2015/10/syria-civil-war-213242

Hugi, Jacky, "Israel Should Back Assad," Al-Monitor, July 1, 2015. As of December 14, 2015:

http://www.al-monitor.com/pulse/originals/2015/07/

israel-syria-war-bashar-al-assad-support-rebels-al-qaeda-is.html

Inbar, Efraim, "How Dangerous Is ISIS to Israel?" Begin-Sadat Center for Strategic Studies, Perspectives Paper 306, September 7, 2015. As of December 14, 2015:

http://besacenter.org/perspectives-papers/how-dangerous-is-isis-to-israel/

“II Prefer ISIS': Iran's Terror Infrastructure Is Greater Threat to Israel-Defense Minister," $R T$, January 20, 2016. As of January 28, 2015: https://www.rt.com/news/329502-isis-iran-threat-israel/

"Iran Has over 1,000 Troops in Iraq, Less Than 2,000 in Syria: U.S. General," Reuters, October 27, 2015. As of December 14, 2015:

http://www.reuters.com/article/

us-mideast-crisis-dunford-iranians-idUSKCNOSL23E20151027\#rUJOA5bpGcF H2ZkW.97

Israel Defense Forces, "Syrian Plane Infiltrates Israeli Airspace, Shot Down," IDF Blog, September 23, 2014. As of December 14, 2015:

https://www.idfblog.com/blog/2014/09/23/

syrian-plane-infiltrates-israeli-airspace-shot/

"Israeli, Russian Deputy Military Chiefs to Coordinate on Syria," Reuters, September 24, 2015. As of December 14, 2015:

http://www.reuters.com/article/2015/09/24/

us-mideast-crisis-israel-russia-idUSKCN0RO0FG20150924

"Israel Targets Syria Army Posts After Rockets Hit Golan," Yahoo! News,

October 13, 2015. As of December 14, 2015:

http://news.yahoo.com/

israel-targets-syria-army-posts-rockets-hit-golan-091719246.html

"Israel to Russia: Reconsider Syria Arms Deal in Light of Mideast Turmoil," Haaretz, April 3, 2011. As of December 14, 2015:

http://www.haaretz.com/israel-news/

israel-to-russia-reconsider-syria-arms-deal-in-light-of-mideast-turmoil-1.353807 
"Israel Worries over Syria’s Golan Pullback," United Press International, April 9, 2013. As of December 14, 2015:

http://www.upi.com/Top_News/Special/2013/04/09/

Israel-worries-over-Syrias-Golan-pullback/UPI-74411365525743/

Jones, Ryan, "Syrian Rocket Fire Hits Northern Israel," Israel Today, September 27, 2012a. As of December 14, 2015:

http://www.israeltoday.co.il/NewsItem/tabid/178/nid/23406/Default.aspx

, "Israel Forced to Consider Military Action in Syria," Israel Today,

October 17, 2012b. As of December 14, 2015:

http://www.israeltoday.co.il/NewsItem/tabid/178/nid/23436/Default.aspx

"Israel Fires Missile at Syria, Northern Residents Prepare for War," Israel Today, November 12, 2012c. As of December 14, 2015:

http://www.israeltoday.co.il/NewsItem/tabid/178/nid/23487/Default.aspx

Jones, Sam, and Erika Solomon, "ISIS Empowered by Shifting Forces in Southern Syria," Financial Times, January 26, 2016.

Judah, Ben, "Israel Welcomes Chaos on Its Borders," Politico, June 16, 2016. As of January 28, 2016:

http://www.politico.eu/article/israel-welcomes-chaos-on-its-borders/

Kais, Roi, "Killing Mughniyeh: Two Rockets, Two Vehicles, and 12 Casualties,"

Ynetnews, January 19, 2015. As of December 14, 2015:

http://www.ynetnews.com/articles/0,7340,L-4616860,00.html

Kaye, Dalia Dassa, and Jeffrey Martini, The Days After a Deal with Iran:

Regional Responses to a Final Nuclear Agreement, Santa Monica, Calif.: RAND

Corporation, PE-122-RC, 2014. As of April 29, 2016:

http://www.rand.org/pubs/perspectives/PE122.html

Koplow, Michael, "The Syrian Crisis and Israeli Security Challenges," oral remarks, Washington, D.C.: Woodrow Wilson International Center for Scholars, December 17, 2015. As of April 29, 2016:

https://www.wilsoncenter.org/event/

the-syrian-crisis-and-israeli-security-challenges

Kuperwasser, Yossi, "Israeli Security Policy in Syria," Jerusalem Center for Public Affairs, April 28, 2015. As of December 14, 2015:

http://jcpa.org/article/israeli-security-policy-in-syria/

Lappin, Yaakov, "Israel, Russia to Coordinate in Air, Sea, and Electromagnetic

Arena,"” Jerusalem Post, September 21, 2015a. As of December 14, 2015:

http://www.jpost.com/Israel-News/Politics-And-Diplomacy/

Israel-Russia-to-coordinate-in-air-sea-and-electromagnetic-arena- 417834
, "Ya'alon: We Made It Clear to Russia That Israel Will Continue to Protect Its Interests," Jerusalem Post, September 29, 2015b. As of December 14, 2015:

http://www.jpost.com/Breaking-News/Yaalon-We-made-it-clear-to-Russia-thatIsrael-will-continue-to-protect-its-interests-419433

"IDF Artillery Strikes 2 Assad Military Targets Following Cross-Border Shelling," Jerusalem Post, October 13, 2015c. As of December 14, 2015: http://www.jpost.com/Middle-East/IDF-artillery-strikes-2-Assad-military-targetsfollowing-cross-border-shelling- 423798

MacFarquhar, Neil, "Russia and Turkey Hurl Insults as Feud Deepens," New York Times, December 3, 2015. As of December 14, 2015:

http://www.nytimes.com/2015/12/04/world/europe/putin-russia-turkey.html

MacFarquhar, Neil, and Anne Barnard, "Putin Orders Start of Syria Withdrawal, Saying Goals Are Achieved," New York Times, March 14, 2016. As of March 15, 2016:

http://www.nytimes.com/2016/03/15/world/middleeast/ putin-syria-russia-withdrawal.html

Morris, Loveday, and Mustafa Salim, "Iran Backs Assad in Battle for Aleppo with Proxies, Ground Troops," Washington Post, October 19, 2015. As of December 14 2015:

https://www.washingtonpost.com/world/middle_east/ iran-backs-battle-for-syrias-aleppo-with-proxies-ground-troops/2015/10/19/ b8bec268-765f-11e5-a5e2-40d6b2ad18dd_story.html

"Nasrallah Confirms Hezbollah, Iran Bolstering Presence Along Golan Border," Jerusalem Post, January 30, 2015. As of December 14, 2015:

http://www.jpost.com/Arab-Israeli-Conflict/Nasrallah-confirms-Hezbollah-Iranbolstering-presence-along-Golan-border-389523

Naylor, Hugh, "Lebanon's Once-Mighty Hezbollah Is Facing Attacks in Syriaand Also at Home," Washington Post, October 28, 2014. As of December 14, 2015: https://www.washingtonpost.com/world/middle_east/

lebanons-once-mighty-hezbollah-is-facing-attacks-in-syria--and-also-at-home/ 2014/10/27/81cd75a4-9d26-4f9b-b843-9fa0814b2471_story.html

Naylor, Hugh, and Andrew Roth, "NATO Faces New Mideast Crisis After Downing of Russian Jet by Turkey," Washington Post, November 24, 2015. As of December 14, 2015:

https://www.washingtonpost.com/world/

turkey-downs-russian-military-aircraft-near-syrias-border/2015/11/24/

9e8e0c42-9288-11e5-8aa0-5d0946560a97_story.html 
"Netanyahu Says Israel Ready to Act Against Syrian Rebels," Israel Today, April 18, 2013. As of December 14, 2015:

http://www.israeltoday.co.il/NewsItem/tabid/178/nid/23796/Default.aspx

Peled, Daniella, "ISIS in Jordan: King Abdullah's Battle for the Soul of Islam," Haaretz, November 25, 2015. As of January 29, 2016:

http://www.haaretz.com/middle-east-news/isis/jordan/1.688313

Peri, Yoram, "The Syrian Crisis and Israeli Security Challenges," oral remarks, Washington, D.C.: Woodrow Wilson International Center for Scholars,

December 17, 2015. As of April 29, 2016:

https://www.wilsoncenter.org/event/

the-syrian-crisis-and-israeli-security-challenges

Pollack, Nadav, "Hezbollah and Israel Are Upping the Ante," Washington Institute for Near East Policy, Policy Alert, August 3, 2015a. As of December 14, 2015:

http://www.washingtoninstitute.org/policy-analysis/view/

hezbollah-and-israel-are-upping-the-ante

"Why Israel Should Be Worried About Russia's Role in Syria," War on the Rocks, October 8, 2015b. As of December 14, 2015:

http://warontherocks.com/2015/10/

why-israel-should-be-worried-about-russias-role-in-syria/

Prime Minister's Office, "PM Netanyahu's Speech at Holocaust Remembrance Day," April 18, 2012. As of January 29, 2015:

http://www.pmo.gov.il/English/MediaCenter/Speeches/Pages/ speechholo180412.aspx

"PM Netanyahu's Remarks at the Start of the Weekly Cabinet Meeting," press release, September 6, 2015a. As of December 14, 2015:

http://www.pmo.gov.il/English/MediaCenter/Spokesman/Pages/

spokeStart060915.aspx

"PM Netanyahu Meets with Russian President Vladimir Putin,"

September 21, 2015b. As of December 14, 2015:

http://www.pmo.gov.il/English/MediaCenter/Events/Pages/

eventPutin210915.aspx

"PM Netanyahu's Speech at the United Nations General Assembly,"

October 1, 2015c. As of December 14, 2015:

http://www.pmo.gov.il/english/mediacenter/speeches/documents/

speechun011015eng.docx
"PM Netanyahu's Speech at the Opening of the Knesset Winter Session,"

October 12, 2015d. As of December 14, 2015:

http://www.pmo.gov.il/English/MediaCenter/Speeches/Pages/

speechWinter131015.aspx

"Putin Said to Be Concerned About Israeli Airstrikes in Syria," Times of Israel, September 29, 2015. As of December 14, 2015:

http://www.timesofisrael.com/

putin-said-to-be-concerned-about-israeli-airstrikes-in-syria/

Raydan, Noam, and Matthew Levitt, "Syria's Druze Under Threat," Washington Institute for Near East Policy, Policywatch 2437, June 17, 2015. As of December 14, 2015:

http://www.washingtoninstitute.org/policy-analysis/view/

syrias-druze-under-threat

"Report: Israel Bombs Syrian Chemical Weapons Base," Israel Today, April 29, 2013. As of December 14, 2015:

http://www.israeltoday.co.il/NewsItem/tabid/178/nid/23816/Default.aspx

Reuters, "Hezbollah Attack Kills 5 'ISIS' Fighters in North Lebanon," Jerusalem Post, October 16, 2015. As of December 14, 2015:

http://www.jpost.com/Middle-East/ISIS-Threat/

Hezbollah-attack-kills-5-ISIS-fighters-in-north-Lebanon-426173

"Rockets Hit Russian Embassy Compound in Damascus," i24news, October 13, 2015. As of December 14, 2015 :

http://www.i24news.tv/en/news/international/88837-151013-israeli-artillerytargets-syria-army-posts-after-rockets-hit-golan

Rudoren, Jodi, "As Syria Reels, Israel Looks to Expand Settlements in Golan Heights," New York Times, October 2, 2015. As of December 14, 2015:

http://www.nytimes.com/2015/10/03/world/middleeast/

syria-civil-war-israel-golan-heights.html

Segal, Udi, "Analysis: Fear of ISIS Takeover of Jordan Drives Israel to Build

Eastern Border Fence," Jerusalem Post, September 14, 2015. As of January 29, 2016:

http://www.jpost.com/Arab-Israeli-Conflict/

Fear-of-ISIS-takeover-of-Jordan-drives-Israel-to-build-eastern-border-fence-416107

Sherwood, Harriet, "US Claims Israel Attacked Russian Missile Shipment in Syria," Guardian, November 1, 2013. As of December 14, 2015:

http://www.theguardian.com/world/2013/nov/01/us-israel-attack-syria-missiles 
"Sykes-Picot Agreement," WWI Document Archive, May 28, 2009. As of April 30, 2016:

http://wwi.lib.byu.edu/index.php/Sykes-Picot_Agreement

"Syria Espionage Case: Israeli Soldier Also Charged," i24news, April 2, 2015. As of December 14, 2015:

http://www.i24news.tv/en/news/israel/

diplomacy-defense/66398-150402-syria-espionage-case-israeli-soldier-also-charged

Times of Israel staff and Joshua Davidovich, "Israeli Strike in Syria Said to Target Samir Kuntar," Times of Israel, July 29, 2015. As of December 14, 2015:

http://www.timesofisrael.com/syria-strike-targeted-samir-kuntar-say-arab-sources/

Torfeh, Massoumeh, "The US Had No Choice but to Involve Iran in Syria Talks," Aljazeera, October 29, 2015. As of December 14, 2015:

http://www.aljazeera.com/indepth/opinion/2015/10/

choice-involve-iran-syria-talks-isil-russia-151028123305678.html

Uni, Assaf, “Inside Israel's Secret War in Syria," Newsweek, June 18, 2015. As of

December 17, 2015:

http://www.newsweek.com/2015/07/03/

israel-secret-war-syria-nusra-druze-344433.html

"UN Personnel Abducted on Israel-Syria Border," Israel Today, March 7, 2013. As of December 14, 2015:

http://www.israeltoday.co.il/NewsItem/tabid/178/nid/23716/Default.aspx
U.S. Senate, Nomination of R. James Woolsey: Hearing Before the Select Committee on Intelligence of the United States Senate, One Hundred Third Congress, First Session, on Nomination of $R$. James Woolsey to Be Director of Central Intelligence, February 2-3, 1993. As of December 3, 2015:

http://www.intelligence.senate.gov/sites/default/files/hearings/103296.pdf

Williams, Dan, "Now Israel Says It Wants to Whack Syria’s Assad," Business Insider, September 17, 2013. As of December 14, 2015:

http://www.businessinsider.com/israel-wants-to-topple-assad-regime-2013-9

Wittes, Tamara, "The Syrian Crisis and Israeli Security Challenges," oral remarks, Washington, D.C.: Woodrow Wilson International Center for Scholars, December 17, 2015. As of April 29, 2016:

https://www.wilsoncenter.org/event/

the-syrian-crisis-and-israeli-security-challenges

Zisser, Eyal, "The Russian and Iranian Military Intervention in Syria," Tel Aviv Notes, Vol. 9, No. 16, September 25, 2015. As of April 29, 2016: http://dayan.org/content/

tel-aviv-notes-russian-and-iranian-military-intervention-syria

Zitun, Yoav, "IDF Sends Reinforcement to North Amid Tensions with Syria, Hezbollah, Iran," Ynetnews, January 22, 2015. As of December 14, 2015: http://www.ynetnews.com/articles/0,7340,L-4618184,00.html

Zityun, Yoav, and Ahiyad Raved, "Eisenkot: IDF Will Prevent Massacre of Syrian Refugees," Ynetnews, June 16, 2015. As of December 14, 2015:

http://www.ynetnews.com/articles/0,7340,L-4669352,00.html 


\section{About This Perspective}

At the end of an extended crisis-simulation game examining Middle East regional security challenges, which RAND Corporation researchers developed and managed, participants noted that neither the player teams nor the control team conceived of a significant role for Israel in the crisis. The chaos along Israel's borders - centered in Syria but affecting Jordan, Lebanon, Egypt, and southern Turkey-had not significantly affected Israel to date, but its principal regional adversaries, Iran and Hezbollah, have been among the primary drivers of the conflict in the Levant. Participants believed that any effort Israel makes to insert itself into the conflict could have a significant impact on its direction; conversely, they believed that an Israeli unwillingness to get involved could signal a reticence to challenge Iran or Russia (which had recently deployed troops to Syria) unless these countries were to pose critical threats to Israel's interests. Participants in the simulation concluded that an assessment of Israel's interests, objectives, and policy options in the Syrian conflict and its main actors would be of interest. This perspective provides that assessment.

The idea for this perspective emerged from a weeks-long crisis simulation involving dozens of Middle East analysts from government agencies,
RAND, and outside institutions. Naming all of the participants in this event would be difficult, but their discussions, insights, and brainstorming identified the need for further research about Israel's interests and objectives regarding the Syria conflict. Richard Girven of the RAND Intelligence Policy Center provided encouragement and support, and both he and Kathleen Reedy, also of RAND, offered perceptive comments on an early draft. David E. Johnson of RAND and Brian Katulis of the Center for American Progress, who served as peer reviewers, offered valuable insights that dramatically improved the paper's arguments and enhanced its usefulness for analysts and policymakers.

This research was sponsored by the Defense Intelligence Agency and conducted within the Intelligence Policy Center of the RAND National Defense Research Institute, a federally funded research and development center sponsored by the Office of the Secretary of Defense, the Joint Staff, the Unified Combatant Commands, the Navy, the Marine Corps, the defense agencies, and the defense Intelligence Community.

For more information on the RAND Intelligence Policy Center, see www.rand.org/nsrd/ndri/centers/intel or contact the director (contact information is provided on the web page).

\section{Limited Print and Electronic Distribution Rights}

This document and trademark(s) contained herein are protected by law. This representation of RAND intellectual property is provided for noncommercial use only. Unauthorized posting of this publication online is prohibited. Permission is given to duplicate this document for personal use only, as long as it is unaltered and complete. Permission is required from RAND to reproduce, or reuse in another form, any of our research documents for commercial use. For information on reprint and linking permissions, please visit www.rand.org/pubs/permissions.html.

The RAND Corporation is a research organization that develops solutions to public policy challenges to help make communities throughout the world safer and more secure, healthier and more prosperous. RAND is nonprofit, nonpartisan, and committed to the public interest.

RAND's publications do not necessarily reflect the opinions of its research clients and sponsors. RAND ${ }^{\circledR}$ is a registered trademark.

For more information on this publication, visit www.rand.org/t/PE185.

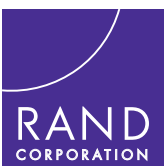

www.rand.org 